\title{
COMPANY MANAGERS' PROPENSITY FOR PARTICIPATIVE DECISION MAKING -A MIXED-METHOD STUDY AMONG TEXTILE INDUSTRIES IN BANGLADESH
}

\author{
Lt Col Md Enamul Islam psc \\ $\mathrm{PhD}$ Research Scholar, \\ Limkokwing University of Creative Technology,
}

\author{
Dr Valiappan Raju \\ Senior Lecturer, \\ Limkokwing University of Creative \\ Technology,
}

Article DOI: $\underline{\text { https://doi.org/10.36713/epra4851 }}$

\begin{abstract}
The study intended to identify if the assumptions of the "Theory $Z$ " serve as predictors of the manager's propensity for participative decision making. Earlier research reports that apart from employee's intent to join in decision-making forum, the manager's tendency is equally essential. The seven assumptions of the "Theory $Z$ ” were assessed for finding managers penchant for participative decision making. This study follows an explanatory sequential mixed method research approach with an emphasis on quantitative results. The sample comprises managers (strategical, tactical and operational) from thirteen Bangladeshi Textile Industries. Findings suggest that Ouchi's assertion of the assumptions of the Theory Z (leadership style, trust, and organisational culture) have reliable predictability for manager's propensity for participative decision making. The study theoretically contributes to the managers' propensity for participative decision-making study by assessing the assumptions of the "Theory Z". Practically, the findings present a convincing argument for managers to challenge their employees' perceptions continually and to analyse objectively how their bias affects their decision-making processes in the least developed countries.
\end{abstract}

KEYWORDS: Theory Z, managers' propensity for participative decision making, leadership, trust, organisational culture, Bangladesh

\section{INTRODUCTION}

Participation is people's mental and emotional involvement in group situations, which allows them to participate and share responsibility for group goals (Bamidele \& Comfort, 2014). Participative decisionmaking (PDM) is a mechanism for employee involvement, administration in sharing decision-related information, and problem-solving (Wagner III, 1994). Although individuals may employ PDM at different organisational levels, this study is concerned entirely with managers utilising PDM. A couple of well-known management theories like Likert's management system theory (1957), McGregor's Theory X/Y (1964), Vroom and Yatton's redefined autocratic-democratic continuum model (1985), and the Theory of Accountability by Kumar (2010) promote PDM.
Recent researches have shifted from the analysis of the method, purpose and modus-operandi of PDM to study why PDM sometimes fails. PDM is a wellpractised business tool for managing people at work and increase in productivity allowing employees to have a voice in the decision making, little is known about the manager's propensity for participative decision making (PPDM). Theoretically, this research joins the queue of PPDM study along with studies carried out by Parnell and Crandall (2001); Parnell (2010); and Parnell, Koseoglu and Dent (2012). The previous PPDM studies were conducted in developed and developing nations with quantitative data. PDM is studied in every part of the world, with a focus on the style of leadership, not on specific theories like Theory Z. 
Enamul and Nilufar (2018) have opined that managers in the Bangladeshi textile industry often superimpose their will and desire on to the employees. Managers do not solicit any feedback from the employees. Islam, Nilufar and Mohammad (2018) in their research, stated that there is a lack of solidarity in Bangladeshi ready-made garments industries which often create chaos and confusion in the industry. Despite several theoretical models describing the degrees of "freedom" that managers grant employees in PDM, there is still a lack of a clear picture of the strengths that influence managers' penchant for PDM. There is a growing need to understand if managers of the Bangladeshi textile industry pose definite proclivity for allowing employees to have to say in the decisionmaking forum. While addressing the literature gap found in the PPDM study, this study also addresses a burning issue of identifying the managers' PPDM in Bangladeshi textile industries. From a scholarly standpoint, this study can extend our understanding of how the individual-difference variables of managers can vary in the degree to which employees are involved in PDM.

This study addresses if assumptions of "Theory Z" predict as managers' PPDM in Bangladeshi textile industries. An explanatory sequential mixed-method design was used, first gathering quantitative data and then describing quantitative findings with in-depth qualitative data (McKim, 2017).

\section{LITERATURE REVIEW}

PDM is associated with workers involved in decisions that typically fall within the domain of the manager (Parnell et al., 2012). Numerous studies suggest that subordinate often prefers participative decision-making regardless of their influence in the organisation (Shaed, Ishak, \& Ramli, 2015). Many researchers argue that participatory decision-making is a broad construct that necessarily associates success with numerous contextual factors (Parnell et al., 2012). The structures of the process of decision making can vary depending on the organisation (Chan et al., 2016). For example, one company may find that PDM is productive and beneficial. Another company may not promote PDM in the organisation (Timming, 2015). Parnell and Crandall (2001, p.531) opined that different organisations might exhibit different reasons for their success or failure in implementing PDM. For example, an organisational culture that promotes participatory approaches and admires productivity can cause reluctant managers to adopt participatory (commitment) attitudes. Managers who reject participation initiatives due to low commitment or perceived power loss may create a culture of indecisiveness (Zubair, Bashir, Abrar, Baig, \& Hassan, 2015).

PPDM study got momentum with the empirical study of Parnell (2010); Parnell \& Crandall (2003); Parnell et al. (2012); and Russ $(2011,2013)$. These authors have empirically researched managers' PPDM in developed and developing nations considering of various management theories. Like Russ (2011) conducted a study to find out if assumptions of McGregor's Theory $\mathrm{X} / \mathrm{Z}$ serves as the predictor of managers' PPDM in the USA. The author suggested that future research may find out if assumptions of the Theory $\mathrm{Z}$ serve as predictors of the manager's propensity for participative decision making. Till today no known research has studied whether the assumptions of the Theory $\mathrm{Z}$ are predicting the manager's PPDM. In 1981, William Ouchi's "Theory Z" ideas were featured in Time magazine as an elaboration of Japan's economic success. Business Week considered him as a founding father of participative management along with Mayo, Maslow, McGregor, and Argyris. Although at first sight, it might be a bit confusing that Theory $\mathrm{Z}$ might be a sequel to McGregor's Theory X and Theory Y, it is not. Ouchi's study of participative management is an explanation of Japanese management success. American corporate world was familiar with the concept of employee involvement in the decision-making process but wondering how the Japanese were doing ahead of them. E. Islam \& Kalimuthu (2020) in their study have found that the assumptions of Theory $\mathrm{Z}$ are a great tool to motivate people at work.

Aydin (2012), in his study, said that Theory Z offers the concept of a hybrid management style which is a combination of a strict American and Japanese management style. Theory $Z$ expresses that an organisational culture that mirrors the Japanese culture in which workers are participative informed and take pride in their works. Theory $\mathrm{Z}$ stresses certain things such as job rotation, broadening of skills, generalisation versus specialisation, and the need for continuous training of workers. He also summarised that while McGregor's Theory X talks about autocratic leadership and management style, Theory $\mathrm{Y}$ is more of setting up targets and needs persuasion. At the same time, Theory $\mathrm{Z}$ seems to be a more democratic approach. Theory $\mathrm{Z}$ hypothesise that some of the assumptions about employees include that workers prefer to build cooperative and friendly working relationships. Theory $\mathrm{Z}$ workers have specific needs to be fulfilled by the company and create a higher value working environment while taking care of the worker's family welfare also (Aydin, 2012). Workers following Theory $\mathrm{Z}$ assumptions have a very well-developed sense of belongings, discipline, high morale, and a sense of 
cohesion and have trust in themselves so extended management can provide a conducive environment (Pandey \& Wali, 2010; Sullivan, 1983).

\subsection{The Link among the Assumptions of Theory $Z$ and Studied Variables}

Drushal (1992) have categorised seven assumptions of Theory $\mathrm{Z}$ into four dimensions such as leadership, trust, communication and participative decision making. The present study has pigeon-holed the seven assumptions into three dimensions and justified that the seven assumptions fall under these dimensions.

\subsubsection{Leadership Style}

Theory $\mathrm{Z}$ premise that human management is more important than machine management (Aithal and Kumar, 2016, p. 4). Managers are necessary for any organisation, while leaders are essential. This study is not about discussing the controversy of managers or leaders' attributes. However, managers should have some leadership quality to manage people at work. There are two types of leaders often seen in any organisation, participative and directive. Theory $\mathrm{Z}$ postulates participative leadership style. A leader can take the workers along with the day to day business and lead them to attain organisational goals. Theory $Z$ postulate that a leader should follow a democratic approach while dealing with workers. If the managers are not motivated to take advantage of PDM, it would rarely be possible to manage people at the workplace. Hence, a hypothesis can be developed that leadership style has a significant positive impact on managers' $\operatorname{PPDM}\left(\mathrm{H}_{1}\right)$.

\subsubsection{Trust}

Theory $\mathrm{Z}$ manager believes that employees are motivated by a strong sense of commitment. Employees will always seek opportunities for taking responsibility, and they will learn more about the company. Here the manager believes that employees learn the business through long-time employment and by making it possible for/her to have "lifetime employment" (Braden, 2000). As stated by Aithal and Kumar, (2016) "Theory Z emphasises the importance of adopting an organisational culture associated with trust, freedom, and collaboration by addressing employees individual needs, personalities, and goals." The fundamental belief of Theory $\mathrm{Z}$ is that average workers want to work and take part in company management (Braden, 2000). Building trust and confidence between employee and employer is also crucial for those enterprises that want to increase productivity. Once proclivity for participative decisionmaking process has a positive sign if he trusts his employees. This argument leads us to hypothesise that managers who trust their employees and find a trustworthy environment in his organisation are more likely to have a definite propensity for the participative decision-making process. Therefore, we can say that trust (between manager and worker) has a significant influence on the manager's proclivity for PDM $\left(\mathrm{H}_{2}\right)$.

\subsubsection{Organisational Culture}

Organisational culture is critical for the effective implementation of employee participation. Managers' propensity is determined by prevailing organisational culture. When the participatory decision-making process is considered as a tool rather than a long-term philosophy are found less successful in the decisionmaking process (Appelbaum et al., 2013; Bhatti \& Qureshi, 2007). Managers are likely to go for a participatory decision-making process if they think it will give a good quality decision and provided it does not take away their power to control the decision (Hollander et al., 1973). Participatory management style is highly successful in an individualistic and lowpower distance society.

In contrast, the authoritarian management style is well suited in a cultural situation where high-power distance prevails in the superior and subordinate relationship (Parnell et al., 2012). In South Asian society, the management style is likely to be both hierarchical and paternalistic. The degree to which workers adhere to the organisation's principles and goals most likely be decided by the organisation's predominant management style. A preferred management style, however, is not evident in all organisations (Basit, Sebastian, \& Hassan, 2017).

Dr Willium Ouchi, through his Theory $\mathrm{Z}$ philosophy, assumes that managers should have a strong philosophical understanding supported by organisational culture setting. Therefore, it can be assumed that organisational culture has an impact on managers' propensity for the participative decisionmaking process $\left(\mathrm{H}_{3}\right)$. Figure 1 shows the pictorial view of the causal relationship between the variables. Three independent variables are leadership style, trust and organisational culture and the dependent variable is PPDM. 
Figure 1: Conceptual Framework and Hypothetical direction

\section{Conceptual Framework and Working Hypotheses}

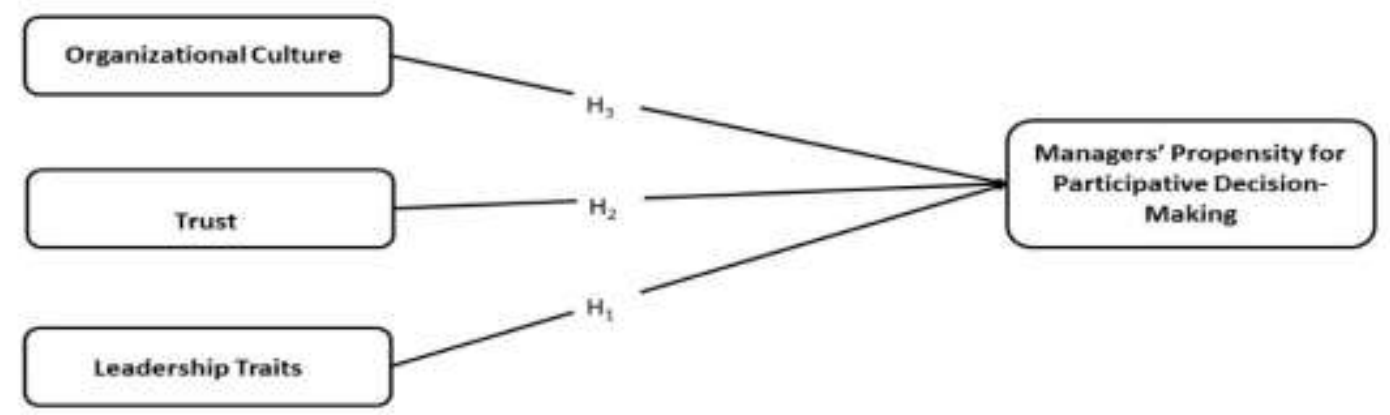

\section{METHODOLOGY}

This research study follows an explanatory sequential mixed-method approach. The study focuses on the managers' penchant for adoption or declination of PDM in day to day business operation. Therefore beside quantitative data, qualitative research is likely to provide rich text data that can be thematically analysed (Creswell \& David, 2018; Greamer, 2018). The unit of analysis is the individual manager working in the textile industries. Managers at all levels (strategic, tactical and operational level) were selected randomly. The research instruments were adapted from existing literature. Research instrument developed by Aarons, Ehrhart and Farahnak (2014) was used for measuring leadership style. Trust scale was adapted from Tzafrir and Dolan (2004). Organisational culture scale is adapted from the Denison Organizational Culture Survey (Denison \& Neale, 1996). The PPDM scale was adapted from a scale developed by Parnell and Crandall (2001). All research instrument has a five-point Likert scale where 1 measured that the respondent strongly disagrees with the given statement, and 5 measured that they strongly agree. The research instrument were pilot tested before going for main study.

The qualitative study used purposive sampling to increase the transferability of the data. Data saturation was decided to be the cut-off point for stopping the qualitative sampling size. Because of COVID-19's effect along the countryside in Bangladesh, 12 out of 21 interviews were conducted online using Zoom Tele broadcasting software. The research instrument contains seven semi-structured open-ended questions asked to all participants.

\section{RESULT AND DISCUSSION}

The research study has two-part. In the first part, the researchers have collected primary data from 364 respondents. The data were analysed to test a given set of hypotheses. The first part of the result will discuss quantitative data analysis. In the second part, the researchers have presented the qualitative findings after collecting rich text data from 21 interviews. This following section will give out quantitative data analysis and qualitative findings.

\subsection{Study 1 - Quantitative Data Analysis}

The broad objective of this research paper is to identify if the assumptions of Theory $Z$ serve as predictors of managers' PPDM in Bangladeshi textile industries. The research adopts the Structural Equation Model (SEM) for data analysis. SEM can test the previous theoretical assumptions against empirical data, statistically. The researchers have conducted a normality test of the data using Mahalobish Distance test using SPSS and found that there are no multivariate outliers in the data set; however, the data are not normally distributed. The model presented in the study is a reflective model where the indicators are pointing towards the latent constructs. As can be seen in Table 1 , Cronbach's " $\alpha$ " is $>.7$ and composite reliability values are above 0.70 . Therefore, it can be assumed that the result indicates good internal consistency and reliability of primary data. The study also achieved convergent validity and discriminant validity (referring to Table 1 and Figure 1). 
Table 1: Reliability and Validity of data

\begin{tabular}{|l|l|l|l|l|}
\hline Latent Constructs & $\begin{array}{l}\text { Cronbach's } \\
\text { Alpha }\end{array}$ & rho_A & $\begin{array}{l}\text { Composite } \\
\text { Reliability }\end{array}$ & $\begin{array}{l}\text { Average } \\
\text { Variance } \\
\text { Extracted } \\
\text { (AVE) }\end{array}$ \\
\hline Leadership Trait (Ldr Trait) & 0.920 & 0.943 & 0.939 & 0.725 \\
\hline Organisational Culture (Org Cul) & 0.923 & 0.937 & 0.942 & 0.764 \\
\hline PPDM & 0.957 & 0.958 & 0.965 & 0.823 \\
\hline Trust & 0.934 & 0.940 & 0.949 & 0.790 \\
\hline
\end{tabular}

Source: Researcher's Primary Data Analysis (SmartPLS)

Figure 1: Path Model showing outer loadings and path coefficient

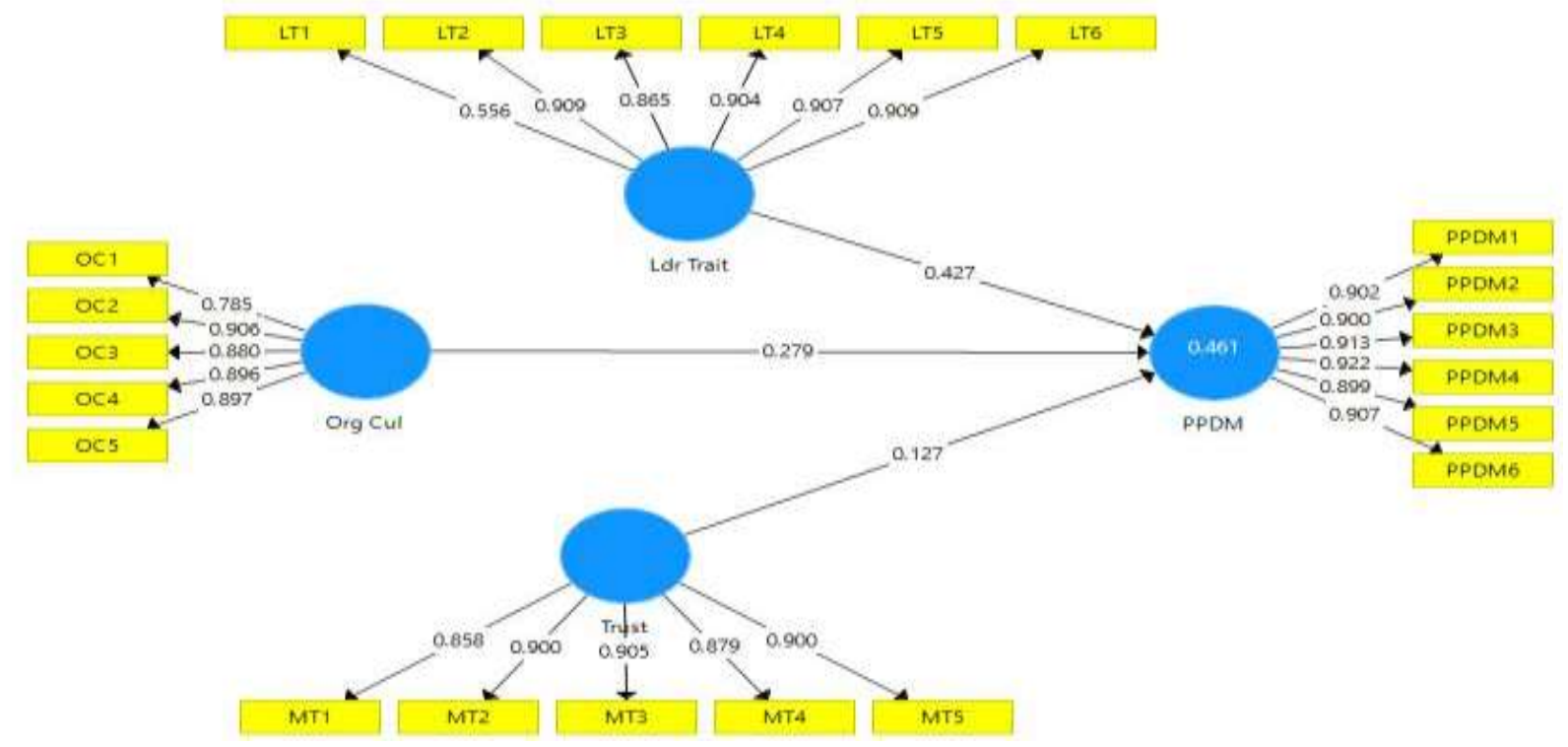

Source: Researcher's primary data analysis

\subsubsection{Result of Hypotheses Testing}

Hypothesis $\mathrm{H}_{1}$ proposed that a leader's traits have a significant influence on their propensity for participative decision-making. The $\mathrm{t}$ value is 7.488 while and $\mathrm{p}<0.05(0.000)$. The result indicates that this hypothesis is supported. Hence this research rejects the null hypothesis in favour of the alternative hypothesis. (see Table 2 for detail).

Hypothesis $\mathrm{H}_{2}$ - trust (between the managers and subordinates) influences managers' PPDM. The quantitative analysis should prove that mutual trust has a substantive effect on managers' proclivity for participative decision-making. The path relationship is significant at 1 percent $(\mathrm{t}=2.651 ; \mathrm{p}$-value is 0.008$)$. This statistical analysis is rejecting the null hypothesis (referring to Table 2 for detail). There is a positive effect of trust on ones' proclivity for participative decision-making. Therefore, the study rejects the null hypothesis and found that the alternative hypothesis is supported.

Table 2: The structural estimates (Direct effect)

\begin{tabular}{|l|l|l|l|l|l|}
\hline $\begin{array}{l}\text { Hypothetical } \\
\text { Relationship }\end{array}$ & Hypothesis & $\begin{array}{l}\text { Sample } \\
\text { Mean }\end{array}$ & $\begin{array}{l}\text { Standard } \\
\text { Deviation }\end{array}$ & T Statistics & P Values \\
\hline Ldr Trait -> PPDM & $\mathrm{H}_{1}$ & 0.429 & 0.057 & 7.488 & 0.000 \\
\hline Trust -> PPDM & $\mathrm{H}_{2}$ & 0.128 & 0.048 & 2.651 & 0.008 \\
\hline Org Cul -> PPDM & $\mathrm{H}_{3}$ & 0.278 & 0.058 & 4.843 & 0.000 \\
\hline
\end{tabular}

Source: Researcher's primary data analysis

Hypothesis $\mathrm{H}_{3}$ - organisational culture might have a significant effect on managers' propensity for the participative decision-making process. The quantitative analysis should demonstrate that 
organisational culture has a functional effect on managers' proclivity for participative decision-making. The path relationship is significant at 1 percent $(\mathrm{t}=4.843 ; \mathrm{p}$-value is 0.000$)$. This statistical analysis rejected the null hypothesis that there is no effect of organisational culture on ones' proclivity for participative decision-making (see Table 2). Therefore, the alternative hypothesis is supported.

\subsection{Study 2 - Qualitative Findings}

The study examined if the assumptions of Theory $\mathrm{Z}$ contribute to predicting managers' use or avoidance of PDM. All three hypotheses were supported. It was imperative to see if the participants have the same view when opinion is sought. The interview received rich text data from which to draw many codes. The data were analysed thematically with the aid of Atlas ti software. Due to space and word limitation, only summary of important findings is presented.

\subsubsection{Summary of the Qualitative findings}

Most managers view this topic as new to them. Primarily the lower-level managers were found having no idea about the formal or informal participative decision-making process. However, the participants felt interested while taking interview being something new to discuss and learn. Significant findings from the qualitative discussion point of view are summarised below:

a. Organisational culture not only influences the way managers to treat their workers but also demonstrates how workers conduct themselves in a specific way.

b. The managers do not have confidence in their employees. The organisation is ignoring a few essential issues such as goal setting, positive feedback, open channel of communication and participation, and innovative suggestions. Traditional aspects of managers denying figuring out new ways to manage people at work.

c. There prevails a high-power within the relationship of the superior and subordinate. Managers penchant for denying sharing their decision-making power is extreme. Making a decision is believed to be absolutely manager's prerogative - a concern which is not suitable for participative decision-making environment.

d. Decision-making process in the case industries is more centralised and executed in a decentralised fashion. The reason behind in autocratic style of taking a decision is that management at the top hierarchal level is not very keen to assign responsibility to the employees at a lower level due to the cultural norms, fear of unknown and stubborn attitude.

e. The hierarchical structure in the case industries is incredibly centralised and formal. Age, seniority and appointment are respected blindly without asking questions and feedback of employees are not considered at all.

f. Industries are yet to develop emotional bondage. Managers are highly concern about information leak. Managers have a firm belief that workers may not sacrifice for the betterment of the organisation and will only remain concerned about wage and benefit.

g. Managers also have the belief that workers might misuse decision making power, and corruption may increase.

h. Managers communication ability is not praiseworthy, which refrain them from communicating with the employees.

i. Dominating character of the managers also posses' severe barriers for PDM.

j. Dishonest and lose character often leads to decide alone and impose forcefully.

k. Disagreement is viewed negatively and a fearful environment refrain employee to take part in decision-making.

\section{CONCLUSION AND GUIDELINE FOR FUTURE RESEARCH}

Dr William Ouchi's Theory Z suggest how the USA managers can gain more productivity following the Japanese management strategies, researchers have proofed that the assumptions are equally applicable to other nations. Even there are many criticisms on this Theory, yet many developed nations have followed it and achieved success in business. The focus of this paper was to understand if the assumptions of Theory $\mathrm{Z}$ predicts as managers' PPDM in Bangladeshi textile industries. The quantitative study supported all three hypotheses. Manager's leadership trait has a significant effect on the manager's PPDM. The research found that mutual trust is also another essential dimension affecting managers' PPDM. The organisational culture embedded with strong philosophy like delegation of authority, holistic concern for employees' family, longterm employment, slow promotion and evaluation is paramount important. The qualitative study justified that Bangladeshi managers do not poeses required proclivity for PDM. Employee loyalty is affected by salary and wages. Employees should be trusted and empowered with responsibility. Managers should believe that consensus in decision-making is likely to 
produce a good quality decision and reduce resistance to change. Managers did not agree with the slow promotion and evaluation process. This idea may not be suitable for a Bangladeshi perspective. Also, longterm employment did not find enough positive response from the participants. These two assumptions may not be effective in Bangladesh. However, managers agreed with sharing some decision-making power. Holistic concern for families was found an excellent tool to motivate employees.

There are certain limitations to the study. The study was conducted on 13 textile industries out of 312 . The sample should have been considered from the maximum number of industries. Only three variables are considered while more attention should have been given like job satisfaction, motivation, organisational climate and managers' locus of control. However, being a pioneer study on managers' PPDM in the least developed country, this research opens many avenues for future research. Future researchers may consider employees' perspective and learn how they think about the implementation of the assumptions for Theory $\mathrm{Z}$. Subsequent studies may wish to extend this line of research by considering managers' avoiding tendency for PDM concerning the Theory of planned behaviour. More considerable attention is needed from researchers and practitioners to understand if an organisational climate influences managers' PPDM.

The researchers hope that current research will instill interest among the managers of Bangladeshi textile industries and other manufacturing industries as well as facilitating to identify the required penchant of the managers for participative management.

\section{REFERENCES}

1. Aarons, G. A., Ehrhart, M. G., \& Farahnak, L. R. (2014). The implementation leadership scale (ILS): Development of a brief measure of unit level implementation leadership. Implementation Science, 9(1), 1-10. https://doi.org/10.1186/17485908-9-45

2. Aithal, S., \& Kumar, S. (2016). Comparative analysis of Theory $X$, Theory $Y$, Theory $Z$, and Theory A for managing people and performance. International Journal of Scientific Research and Modern Education, 1(1), 803-812. https://doi.org/10.1227/01.NEU.0000349921.14519 $.2 A$

3. Akhter, S., Saha, S. P., \& Mahfuz, I. (2019). Participative Management and Job Satisfaction : A Case of Bangladesh. World Journal of Management, 10(1), 45-56.

4. Akpoviroro, K. S., Kadiri, B., \& Owotutu, S. O. (2018). Effect of Participative Leadership Style on Employees Productivity. Journal of Economic Behaviour, $\quad 8(2), \quad$ 47-60. https://doi.org/10.24132/jbt.2018.8.2.48_58
5. Aktar, A., \& Pangil, F. (2018). Mediating role of organisational commitment in the relationship between human resource management practices and employee engagement: Does the black box stage exist? International Journal of Sociology and Social Policy (Vol. https://doi.org/10.1108/IJSSP-08-2017-0097

6. Ali, M. R., Khaleque, A., \& Hossain, M. (1992). Participative Management in a Developing Country: Attitudes and perceived barriers. Journal of Managerial Psychology, 7(1), 11-16. https://doi.org/10.1108/02683949210012995

7. Ali, N. M., Jangga, R., Ismail, M., Kamal, S. N.-I. M. \& Ali, M. N. (2015). Influence of Leadership Styles in Creating Quality Work Culture. Procedia Economics and Finance, 31(15), 161-169. https://doi.org/10.1016/S2212-5671(15)01143-0

8. Anderson, J. C., \& Gerbing, D. W. (1988). Structural Equation Modeling in Practice: A Review and Recommended Two-Step Approach. Psychological Bulletin, 103(3), 411-423. https://doi.org/10.1037/0033-2909.103.3.411

9. Anwar, A. (2018). A Case Study Measuring the Effectiveness of Leadership Training for Women Leaders Across Bangladesh. UITS Journal, 5(1), 522.

10. Appelbaum, S. H., Louis, D., Makarenko, D., Saluja, J., Meleshko, O., \& Kulbashian, S. (2013). Participation in decision making: A case study of job satisfaction and commitment (part one). Industrial and Commercial Training, 45(4), 222229. https://doi.org/10.1108/00197851311323510

11. Aydin, O. T. (2012). The Impact of Theory $X$, Theory $Y$ and Theory $Z$ on Research Performance: An Empirical Study from A Turkish University. International Journal of Advances in Management and Economics, 1(5), 24-31.

12. Bamidele, M. A., \& Comfort, E. (2014). Workers participation in decision making and job satisfaction among university academic staff. The International Research Journal, 2(2), 23-31. https://doi.org/10.1177/0143034312472758

13. Barney, J. B. (2004). Introduction: William Ouchi's Theory Z: How American business can meet the Japanese Challenge. Academy of Management Executive, 18(4), 106-107. https://doi.org/10.5465/AME.2004.15268703

14. Basit, A., Sebastian, V., \& Hassan, J. (2017). Impact of Training on Employee Performance: A Case Study of Private Organization in Sri Lanka. IOSR Journal of Business and Management, 5(2), 112-130. https://doi.org/DOI: 24924/ijabm/2017.11/v5.iss2/112.130

15. Bhatti, K. K., \& Qureshi, T. M. (2007). Impact of Employee Participation on Job Satisfaction, Employee Commitment and Employee Productivity. International Review of Business ..., 3(2), 54-68.

16. Bhuiyan, A. H. (2010). Employee Participation in Decision Making in the RMG sector of Bangladesh: Correlation with Motivation and Performance. 
Journal of Business and Technology (Dhaka), 5(2), 2001-2002. https://doi.org/10.3329/jbt.v5i2.9984

17. Braden, P. A. (2000). Participative Management Styles: Theory Z - William Ouchi. Parkersburg: Division of Business \& Economics.

18. Chan, S. W., Omar, A. R., Ramlan, R., Omar, S. S., Lim, K. H., \& Zaman, I. (2016). Assessing participation in decision-making among employees in the manufacturing industry. 3rd International Conference on Industrial Engineering, Management Science and Applications, (c), 1-5. https://doi.org/10.1109/ICIMSA.2016.7503997

19. Chennamaneni, A. (2006). Determinants of Knowledge Sharing Behaviours: Developing And Testing An Integrated Theoretical Model. Thesis, (December), 148.

20. Creswell, J. (2006). Choosing A Mixed Method Design. Research Methodology (pp. 58-89). Sage publications. https://doi.org/1412927927

21. Creswell, J. W., \& David, J. C. (2018). Research Design. Qualitative, Quantitative and Mixed Method Approaches (5th ed.). London: Sage.

22. Daft, R. L. (2004). Theory Z: Opening the corporate door for participative management. Academy of Management Executive, 18(4), 117121. https://doi.org/10.5465/AME.2004.15268709

23. Drushal, M. E. (1992). Motivational Components of Theory Z Management: An Integrative Review of Research and Implications for the Church. Networks and Heterogeneous Media, 11(1), 8-27. https://doi.org/10.3934/nhm.2016.11.107

24. Enamul, I., \& Nilufar, Y. (2018). Significance of Negotiation Skills for Bangladeshi HR Manager in Private Business Organization. Elixir International Journal, 120, 51230-51234.

25. Fornell, C., \& Larcker, D. F. (1981). Structural Equation Models with Unobservable Variables and Measurement Error: Algebra and Statistics. Journal of Marketing Research, 18(3), 382-388. https://doi.org/10.2307/3150980

26. Greamer, E. G. (2018). An Introduction to Fully Integrated Mixed Methods. New Delhi: Sage.

27. Hair, Joe F., Ringle, C. M., \& Sarstedt, M. (2011). PLS-SEM: Indeed, a Silver Bullet. Journal of Marketing Theory and Practice, 19(2), 139-151. https://doi.org/10.2753/MTP1069-6679190202

28. Hair, Joe F., Sarstedt, M., Hopkins, L., \& Kuppelwieser, V. G. (2014). Partial least squares structural equation modelling (PLS-SEM): An emerging tool in business research. European Business Review, 26(2), 106-121. https://doi.org/10.1108/EBR-10-2013-0128

29. Hair, Joseph F., Black, W. C., Babin, B. J., \& Anderson, R. E. (2014). Multivariate Data Analysis. Prentice-Hall, Inc (7th ed., Vol. 1). Pearson Education Limited. https://doi.org/10.1038/259433b0

30. Hair, Joseph F., Ringle, C. M., \& Sarstedt, M. (2013). Partial Least Squares Structural Equation Modeling: Rigorous Applications, Better Results and Higher Acceptance. Long Range Planning, 46(1-2), $1-12$. https://doi.org/10.1016/j.lrp.2013.01.001

31. Hair, Joseph F, Risher, J. J., Sarstedt, M., \& Ringle, C. M. (2018). When to Use and How to Report the Results of PLS-SEM. European Business Review, 31(1), 2-24. https://doi.org/https://doi.org/10.1108/EBR-112018-0203

32. Harzing, A. W., Maznevski, M., Fischlmayr, I., Yaconi, L. L., Wittenberg, K., Myloni, B., ... Feely, A. (2002). The interaction between language and culture: A test of the cultural accommodation hypothesis in seven countries. Language and Intercultural Communication, 2(2), 120-139. https://doi.org/10.1080/14708470208668081

33. Henseler, J., Ringle, C. M., \& Sarstedt, M. (2015). A new criterion for assessing discriminant validity in variance-based structural equation modelling. Journal of the Academy of Marketing Science, 43(1), 115-135. https://doi.org/10.1007/s11747014-0403-8

34. Hoa, T. T. B., \& Hoa, N. Van. (2015). Theory Z and Science and Technology Human Resources Development Policy of Japan in 21 CenturyLesson Suggested for Vietnam. JSTPM, 4(4), 108124.

35. Hollander, E. P., Vroom, V. H., Yetton, P. W., Hollander, E. P., Vroom, V. H., Yetton, P. W., ... Yetton, P. W. (1973). Leadership and decisionmaking. Administrative Science Quarterly. Pittsburgh: University of Pittsburgh Press. https://doi.org/10.2307/2392210

36. Islam, E. (2020). Monitoring Impact of Social Dominance Orientation in Bangladeshi Manufacturing Industries. Business and Economic Research, 10(1), 251-259. https://doi.org/10.5296/ber.v10i1.16254

37. Islam, M. E., \& Kalimuthu, R. (2020). Assumptions of Theory Z: A Tool for Managing People at Work. The Asian Journal of Professional and Business Studies, 1(1).

38. Islam, M. E., Nilufar, Y. M. \& Mohammad, F. (2018). Corporate Social Responsibility of RMG Industry to Secure Future Vulnerability on Workers Retired Life. Global Journal of Management and Business: A Administration and Management, 18(7), 1-15.

39. Islam, S., \& Eva, S. A. (2017). Application of Mcgregor's Theory $X$ and Theory Y: Perception of Management toward the Employees in the Banking Industry of Bangladesh. The International Journal Of Business \& Management, 5(11), 135-145.

40. Ivankova, N. V., Creswell, J. W., \& Stick, S. L. (2006). Using Mixed-Methods Sequential Explanatory Design: From Theory to Practice. Field Methods, 18(1), 3-20. https://doi.org/10.1177/1525822X05282260

41. Krejcie, R. V, \& Morgan, D. (1970). Determining Sample Size for Research Activities. Educational 
and Psychological Measurement, 30, 607-610. https://doi.org/https://doi.org/10.1177\%2F0013164 47003000308

42. Marks, M. L., Mirvis, P. H., Hackett, E. J., \& Grady, J. F. (1986). Employee participation in a Quality Circle program: Impact on quality of worklife, productivity, and absenteeism. Journal of Applied Psychology, 71(1), 61-69. https://doi.org/10.1037/0021-9010.71.1.61

43. Matsuo, M. (1983). Japanese Management: Theory Zero, not Theory Z. Graduation Student Theses \& Professional Paper, Tokyo, Japan.

44. McKim, C. A. (2017). The Value of Mixed Methods Research: A Mixed Methods Study. Journal of Mixed Methods Research, 11(2), 202-222. https://doi.org/10.1177/1558689815607096

45. Miah, M. K., \& Islam, M. M. (2017). Human Resource Management Practices and Organisational Performance: Evidence from Japanese and US Subsidiaries / Joint Venture in Bangladesh. Journal of Human Resource Management, $X X(1)$.

46. Pandey, S. K., \& Wali, O. P. (2010). Management lessons from Indian epics in context to theory $Z$. Journal of Human Values, 16(1), 57-70. https://doi.org/10.1177/097168581001600106

47. Parashar, B. K. (2016). Significance of Theory Z in Indian Scenario. International Journal of Management and Social Sciences Research (IJMSSR), 5(2), 8-16.

48. Parnell, J. A. (2010). The propensity for participative decision making in Latin America: Mexico and Peru. International Journal of Human Resource Management, 21(13), 2323-2338. https://doi.org/10.1080/09585192.2010.516588

49. Parnell, J. A., \& Bell, E. D. (1994). The Propensity for Participative Decision Making Scale. Administration \& Society, 25(4), 518-530.

50. Parnell, J. A., \& Crandall, W. (2001). Rethinking Participative Decision Making. Personnel Review, 30(5), https://doi.org/10.1108/EUM0000000005937

51. Parnell, J. A., \& Crandall, W. (2003). Propensity for Participative Decision-Making, Job Satisfaction, Organizational Commitment, Organizational Citizenship Behavior, and Intentions to Leave Among Egyptian Managers. Multinational Business Review, 11(1), 45-65. https://doi.org/http://dx.doi.org/10.1108/1525383X 200300003

52. Parnell, J. A., Koseoglu, M., \& Dent, E. (2012). The propensity for Participative Decision Making (PPDM) In Turkey and the USA. Int. J. Business Excellence, $\quad 5(3), \quad 278-304$ https://doi.org/10.2139/ssrn.2331200

53. Peng, D. X., \& Lai, F. (2012). Using Partial Least Squares in Operations Management Research: A Practical Guideline and Summary of Past Research. Journal of Operations Management, 30(6), https://doi.org/10.1016/j.jom.2012.06.002

54. Rigdon, E. E. (2016). Choosing PLS path modelling as an analytical method in European management research: A realist perspective. European Management Journal, 34(6), 598-605. https://doi.org/10.1016/j.emj.2016.05.006

55. Rita, L. (2010). Measuring the Impact of Leadership Style and Employee Empowerment on Perceived Organizational Reputation (Vol. 9). https://doi.org/10.1558/jsrnc.v4il.24

56. Russ, T. L. (2011). Theory $X / Y$ assumptions as predictors of managers' propensity for participative decision making. Management Decision, $\quad 49(5), \quad 823-836$. https://doi.org/10.1108/00251741111130887

57. Russ, T. L. (2013a). The Influence of Communication Apprehension on Superiors' Propensity for and Practice of Participative Decision Making. Communication Quarterly, 61(3), 335-348.

https://doi.org/10.1080/01463373.2013.776989

58. Russ, T. L. (2013b). The relationship between Theory $X / Y$ : assumptions and communication apprehension. Leadership \& Organization Development Journal, 34(3), 238-249. https://doi.org/http://dx.doi.org/10.1108/014377313 11326675

59. Sarstedt, M., Hair, J. F., Ringle, C. M., Thiele, K. O., \& Gudergan, S. P. (2016). Estimation Issues with PLS and CBSEM: Where the bias lies! Journal of Business Research, 69(10), 3998-4010. https://doi.org/10.1016/j.jbusres.2016.06.007

60. Sarstedt, M., Ringle, C. M., \& Hair, J. F. (2017). Partial Least Squares Structural Equation Modeling. Hamburg: Springer International Publishing.

https://doi.org/https://doi.org/10.1007/978-3-31905542-8_15-1

61. Sekaran, U., \& Bougie, R. (2016). Research Methods for Business. A Skill Building Approach (7th ed.). West Sussex: John Wiley \& Sons Ltd.

62. Shaed, M. M., Ishak, S., \& Ramli, Z. (2015). Employee $s$ 'Participation in Decision Making ( PDM ): A literature survey. Malaysian Journal of Society and Space, 13(11), 142-155.

63. Siddiqua, S., Chowdhury, M. A. M., \& Islam, M. R. (2014). Industrial Relation and Dispute Settlement Procedure in the RMG Sector of Bangladesh: A Critical Review. International Journal of Innovation and Applied Studies, 9(3), 1233-1244.

64. Sullivan, J. J. (1983). A Critique of Theory $Z$. Academy of Management, 8(1), 132-142.

65. Sun, S. (2008). Organizational Culture and Its Themes. International Journal of Business and Management, 3(12), 137-141. https://doi.org/10.5539/ijbm.v3n12p137

66. Tabachnic, B. G., \& Fidell, L. S. (2007). Using Multivariate Statistics (2nd ed.). Boston: Allyn and Bacon.

67. Tabachnick, B. G., \& Barbara, T. (2019). Using 
Multivariate Statistics. In Multivariate Statistics (7th ed., pp. 1-14). California: Pearson Education Limited. https://doi.org/10.1007/978-94-009-12175

68. Tabachnick, G., \& Fidell, L. S. (2013). Using Multivariate Statistics (6th ed.). New York: Pearson.

69. Timming, A. R. (2015). The "reach" of employee participation in decision-making: Exploring the Aristotelian roots of workplace democracy. Human Resource Management Journal, 25(3), 382-396. https://doi.org/10.1111/1748-8583.12050

70. Trivikram, S. (2017). Assumptions of Theory X and Theory Y. Retrieved May 2, 2019, from https://myventurepad.com/assumptions-theory- $x$ theory-y/

71. Tzafrir, S. S., \& Dolan, S. L. (2004). Trust Me: A Scale for Measuring Manager-Employee Trust. Journal of the Iberoamerican Academy of Management, 2(2), 115-132.

72. Ubaidullah, M. R. (2015). Challenges and Prospects of Industrial Relations in the RMG Sectors of Bangladesh. Bangladesh Tariff Commission Publication, 1(2), 1-30.
73. Vaismoradi, M., Turunen, H., \& Bondas, T. (2013). Content analysis and thematic analysis: Implications for conducting a qualitative descriptive study. Nursing and Health Sciences, 15(3), 398-405. https://doi.org/10.1111/nhs. 12048

74. Venkatesh, V., Brown, S. A., \& Stukalina, Y. (2016). Guidelines for Conducting Mixed-methods Research: An Extension and Illustration. Journal of the Association for Information Systems, 17(7), 435-495. https://doi.org/Retrieved from http://aisel.aisnet.org

75. Wagner III, J. A. (1994). Participation's Effects on Performance and Satisfaction: A Reconsideration of Research Evidence. Academy of Management Review, 19(2), 312-330. https://doi.org/10.5465/AMR.1994.9410210753

76. Zubair, A., Bashir, M., Abrar, M., Baig, S. A., \& Hassan, S. Y. (2015). Employee's Participation in Decision Making and Manager 's Encouragement of Creativity: The Mediating Role of Climate for Creativity and Change. Journal of Service Science and Management, 8(June), 306-321. https://doi.org/http://dx.doi.org/10.4236/jssm.2015. 83033. 